Prof. dr. sc. Duško Lozina, redoviti profesor

Pravni fakultet Sveučilišta u Splitu

\title{
NOVI TRENDOVI U RAZVOJU HRVATSKE UPRAVNE ZNANOSTI
}

\author{
UDK: 342 (497.5) \\ Primljeno: 10. rujan 2017. \\ Pregledni rad
}

Ovaj kratki i nepretenciozno napisani tekst ima kao temeljnu nakanu upozoriti na nastanak novih trendova unutar recentne hrvatske upravne znanosti. Riječ je o činjenici da se sve više kolegica na Katedri upravne znanosti pri Pravnom fakultetu Sveučilišta u Zagrebu pojavilo kao znanstvenonastavno osoblje u nekada gotovo isključivo „muškoj“ disciplini.

Pritom treba pozdraviti njihovo autoritativno i profesionalno bavljenje svim aspektima discipline, kako sadržajno-tradicijskih, tako i otvaranjem novih tematskih područja. Posebice je velika zasluga nastavnica upravne znanosti u procesu europeizacije hrvatske javne uprave i nastojanje na ukazivanju nedostataka aktualnog stanja s preporukama za njihovo otklanjanje.

Hrvatska upravna znanost na ovaj način hvata priključak na suvremena zbivanja unutar discipline u europskom kontekstu. Širinom i obuhvatom tema, starih i novih, hrvatska upravna znanost svjedoči svoju vitalnost te pokazuje da se može ravnopravno nositi s korpusom pozitivnopravnih disciplina, a možda i više od ove konstatacije.

Ključne riječi: javna uprava, lokalna samouprava, europeizacija, menadžerske reforme, transparentnost, otvorenost, agencije

Kada smo prije gotovo 20-tak godina reflektirali o stanju i perspektivama discipline upravne znanosti u Hrvatskoj, zauzeli smo poprilično pesimističan stav. Tu smo prije svega mislili naumirovljenje nestora upravne znanosti akademika Eugena Pusića, europski prepoznatljivog autora, koji je i nakon umirovljenja nastavio punim intenzitetom razvijati disciplinu u stručnom i u metodičnom smislu. Na taj način disciplina je dobila na svom kredibilitetu i snažnu teorijsku impostiranost. Vrijeme je pokazalo da onom pomalo pesimističnom stavu nije bilo mjesta, te smo svjedoci pravog procvata te discipline, posebice pri Katedri upravne znanosti Pravnog fakulteta Sveučilišta u Zagrebu koju vodi prof. dr. sc. Ivan Koprić, ujedno i utemeljitelj Instituta za javnu upravu, koji pod svojom egidom okuplja respektabilan broj hrvatskih i inozemnih stručnjaka s područja upravne znanosti i upravnog prava. Naravno da naša namjera nije motivirana spolnom diskriminacijom, već nam je cilj prije svega upozoriti na činjenicu da se pojavilo nekoliko nastavnica koje daju snažnu intelektualnu svježinu i tematski produbljuju spoznaje o problematici javne uprave.

U vrijeme kada je akademik Eugen Pusić bio alfa i omega hrvatske upravne znanosti, činilo se da je riječ o disciplini prožetoj gotovo isključivo dominacijom 
muškaraca. Naime, prvi suradnici akademika Pusića bili su eminentni profesori Ivanišević, Pavić i Ramljak. Slična situacija bila je i na ostalim pravnim fakultetima u državi, i to u Osijeku, Rijeci i u Splitu. Izuzetak od tog nepisanog pravila bila je uvažena prof. dr. sc. Inge Perko-Separović koja se etablirala u respektabilnu profesoricu predavajući naznačeni kolegij na FPZ-u Sveučilišta u Zagrebu i koja je napisala nekoliko značajnih knjiga, navlastito 70-tih godina 20. stoljeća kada je među ostalima publicirala knjige ,Teorija organizacije“ i ,Tehnologijamoć-samoupravljanje“, promišljajući u novije vrijeme i tematiku novog javnog menadžmenta, posebice britanski model. Hrvatska upravna znanost, kako smo ustvrdili, bila je u to vrijeme pretežito „muška“ disciplina, uz rečeni izuzetak prof. dr. sc. Perko-Separović. No, s krajem 20. i početkom 21. stoljeća upravna znanost u Hrvatskoj dobiva novu dinamiku i akceleraciju, a sama Katedra upravne znanosti pri Pravnom fakultetu Sveučilišta u Zagrebu postala je najmnogoljudnija katedra, zaslužna za afirmaciju discipline ne samo u hrvatskim uvjetima, nego i šire.

Disciplina se počela razvijati u svekolikom smislu, posebice u sadržajnotematskom, hvatajući tako priključak s europskim standardima i problemskim kontekstom. Ono što se može primijetiti jest snažan porast broja kolegica koje se autoritativno i ozbiljno bave problematikom upravne znanosti, ističući jake intelektualne osobnosti.

Unutar hrvatske upravne znanosti snažnu teorijsku afirmaciju postižu kolegice poput prof. dr. sc. Gordane Marčetić, doc. dr. sc. Anamarije Musa, koja je istodobno i Povjerenica Vlade RH za informiranje od 2013. godine, doc. dr. sc. Romee Manojlović, doc. dr. sc. Jasmine Džinić, doc. dr. sc. Goranke Lalić-Novak, dr. sc. Tijane Vukojičić, politologinje Petre Đurman, mag. iur. Darie Dubajić, mag. iur. Ive Lopužić.

Navedene kolegice dale su snažan osobni i kolektivni obol, posebice na planu konvergencije javne uprave u Hrvatskoj sa širim europskim upravnim prostorom, navlastito $\mathrm{u}$ promoviranju procesa europeizacije $\mathrm{i} u$ akceptiranju europskih upravnih vrijednosti u rad javne uprave u Hrvatskoj, u kojoj još uvijek egzistiraju i weberijanske oznake uprave.

Tematika kojom se one bave vrlo je široka po svom obuhvatu i vrlo raznolika. Tako primjerice, bave se problematikom tranzicije, razvojem novih oblika upravnih doktrina, organizacijskih načela, menadžerskih metoda u upravi, problematikom javnih i državnih službenika u Hrvatskoj i u europskim zemljama, zatim problematikom etike u javnoj upravi, primjeni novih metoda kao što je uvođenje elemenata e-uprave u rad javne uprave u hrvatskim prilikama, problematikom azila i prava migranata, problemom zastupljenosti nacionalnih manjina, tematikom transparentnosti i otvorenosti u djelovanju javne uprave, agencifikacijom, pravom na pristup informacijama, participacijom građana u radu uprave, učinkovitošću djelovanja upravnih organizacija, sve do prikaza stanja i problema unutar područja lokalne samouprave u brojnim europskim zemljama, problemom koordinacije u upravnim organizacijama, dakle čitavim spektrom kojima se bavi moderna upravna znanost u razvijenim europskim zemljama. 
$\mathrm{Na}$ ovaj način autorice pokazuju da i relativno male države kao što je Hrvatska mogu iznjedriti snažne osobnosti poput brojnih kolegica u drugim europskim državama, posebice onih demokratske provenijencije. Nakana je ovog eseja da barem informativno prozbori o osnovnim teorijskim interesima i interpretativnim obolima apostrofiranih kolegica.

Prof. dr. sc. Gordana Marčetić autorica je i koautorica nekoliko značajnih knjiga s ovog područja. Tu mislimo na knjige kao što su „Javni službenici i tranzicija“ iz 2005. godine, zatim „Upravljanje ljudskim potencijalima u javnoj upravi“ iz 2007. godine, te na njezin koautorski doprinos u knjigama „Europeizacija hrvatske javne uprave“ iz 2014. godine te „Etika u politici i javnoj upravi“ iz 2016. godine.

Prof. Marčetić pokazuje snažan interes za problem tranzicije i vrlo detaljno spominje glavne predstavnike te tematike, naglašavajući osobito dvije glavne faze tranzicijskog procesa - liberalizaciju i demokratizaciju. Ova autorica posebice naglašava značaj reafirmacije ekonomskih vrijednosti u javnoj upravi, koja je potaknuta neracionalnošću i rastrošnošću socijalne države u uvjetima ekonomske krize 70-tih godina prošlog stoljeća. Zalaže se za vladavinu meritokracije, što znači najsposobnijih i najobrazovanijih pojedinaca, u radu upravnih organizacija. Pritom autorica zamjećuje da su članovi novih upravnih elita u postsocijalističkim društvima zapravo pripadnici nekadašnje nomenklature. Prof. Marčetić smatra da u optimalnom slučaju tranzicijske zemlje ne bi trebale dopustiti međunarodnoj okolini određivanje i kontroliranje njihova tranzicijskog procesa u toj mjeri da uguši svaku odluku koja nije u globalnom interesu. Drugim riječima, ona se zalaže za različit pristup izgradnji službeničkih sustava u različitim zemljama. U tematskom smislu, knjizi „Javni službenici i tranzicija“ slična je i knjiga „Upravljanje ljudskim potencijalima u javnoj upravi“ gdje se ljudski potencijali definiraju kao ukupnost formalnih znanja, praktičnih vještina, sposobnosti ponašanja, socijalnih obilježja, psiholoških osobina te realiziranih ili latentnih kreativnih mogućnosti ljudi u nekom društvu, organizaciji ili zajednici.Upravljanje ljudskim potencijalima izum je doktrine novog javnog menadžmenta. Ono isključuje svaki amaterizam i diletantizam u području ljudske kreativnosti u javnoj upravi.

Za razliku od administrativno-birokratskog modela koji eksplicitno naglašava pravne i demokratske vrijednosti, no implicitno obuhvaća i socijalne komponente, novi integralni ili sintetizirani model osobito promovira načela nepristranosti, profesionalizma i odazivnosti. Autorica naglašava značaj učeća organizacije i cjeloživotnog obrazovanja. U metodičkom smislu, Marčetić se oslanja na postavke institucionalne teorije, te drži da za razliku od starog institucionalizma, koji se ograničavao na pravno formalizirane strukture, novi institucionalizam uspostavlja analitičku svezu između političkih struktura, procesa i sadržaja.

Privatizacija javnih službi, deregulacija, decentralizacija, stvaranje javnog tržišta, marketizacija, ugovaranje, usmjeravanje na rezultate i smanjenje na svim razinama javnih troškova, javnih organizacija i broja javnih službenika znatno su promijenili tradicionalnu sliku javne uprave. 
Značajan je doprinos prof. Marčetić dala i razumijevanju problematike etike u javnoj upravi, čime dotiče i filozofijski pristup uz klasični upravni i politologijski, što je legitimira kao multivalentnog istraživača javne uprave. Kao glavne elemente etičkog vrijednosnog okvira u javnom sektoru mogu se svrstati integritet, transparentnost, odgovornost, zaštićenost, ljudsko dostojanstvo, poštenje i povjerenje, dosljednost i harmonija interesa, pravednost, autentičnost, samoidentifikacija, sloboda izražavanja i profesionalizam.

Etički kodeks službenika su, primjerice, u 2014. godini u Hrvatskoj usvojile 142 jedinice lokalne i područne samouprave od njih ukupno 576. Naravno da smo posve svjesni kako prikazom ovih magistralnih teorijskih preokupacija prof. Marčetić nije moguće sa stajališta ovoga rada pokazati čitav spektar njezinih spoznaja o javnoj upravi.

Druga značajna predstavnica tzv. ,zagrebačke škole“ upravne znanosti jest doc. dr. sc. Anamarija Musa. Njezin ključni obol razvitku upravne znanosti sadržan je u knjizi „Agencijski model javne uprave“ čime se očitovala kao jedan od najvrsnijih poznavatelja te problematike u Hrvatskoj. Anamarija Musa u svom metodologijskom stavu polazi od institucionalne teorije, posebno naglašavajući značaj sociološkog institucionalizma. Koherentnost i autonomija predstavljaju esencijalna obilježja institucija.

Institucije pripomažu standardizaciji ponašanja, homogenizaciji i autorizaciji zajedničke svrhe. Autorica se referira i na novi institucionalizam racionalnog izbora koji se pojavljuje 80-tih godina 20. stoljeća iz tada dominantne teorije racionalnog izbora. Historijski institucionalizam kao još jedna inačica ima za temeljnu poruku važnost povijesti i zaokupljen je povijesnom uvjetovanošću tijeka i rezultata političkog procesa u kojem ključnu ulogu za institucionalni razvoj imaju prije svega odabrani smjerovi djelovanja i vremenski redoslijed.

Anamarija Musa ustvrđuje da se danas govori o agencifikaciji, eksploziji „quanga“, „,agencijskoj modi“, „vladanju putem punomoći“ kao trendu pod utjecajem neomenadžerske doktrine i ideje regulacijske države. Regulacijske reforme pojavljuju se u gospodarskim javnim službama kao što su telekomunikacije, promet, energenti, zajedno s liberalizacijom i privatizacijom javnih poduzeća. Autorica ustvrđuje da su se pokazale i prve boljetice doktrine novog javnog menadžmenta i zamjena s doktrinom dobre vladavine. Načela dobrog upravljanja jesu participacija, vladavina prava, transparentnost, odazivnost, orijentacija na konsenzus, pravičnost i uključivost, odgovornost te učinkovitost i efikasnost.

Agencijski model javne uprave odlikuju specijalizacija i samostalnost, za razliku od klasične državne uprave sastavljene s horizontalnom diferencijacijom, funkcionalnom specijalizacijom, te stvarnom decentralizacijom u javnom sektoru te pojačava probleme koordinacije. Poseban segment interesa Anamarije Musa uz tematiku agencifikacije, vezan je uz problem europeizacije. Proces europeizacije najvidljiviji je na primjeru javnih politika, jer europska regulativa ili određuje model javne politike ili postavlja parametre i ograničenja nacionalnom oblikovanju politika. 
Autorica naglašava da europeizacija nije isto što i konvergencija, harmonizacija ili politička integracija, ali da to mogu biti njezine posljedice.

Anamarija Musa bavi se u svom radu i vrlo popularnim pojmom governance. Smatra da su dva osnovna shvaćanja pojma governance u javnoj upravi uže shvaćanje prema kojem je riječ o upravljanju mrežama i šire shvaćanje prema kojem je governance proces izrade, primjene i nadzora primjene pravila javne politike i njezine implementacije.

Kada je riječ o europskom upravnom prostoru, autorica naglašava da on predstavlja zajednički model ili jezgru upravnih institucija, pravila, postupaka i prakse koji su zajednički svim članicama EU-a. Glavna načela koja obilježavaju EUP jesu: a) vladavina prava; b) otvorenost i transparentnost; c) odgovornost javne uprave; d) efikasnost. Najveći broj agencija u Hrvatskoj osnovan je u području zdravstva, znanosti, obrazovanja i istraživanja, prometa i telekomunikacija, poljodjelstva, financija, gospodarstva, regionalnog razvoja i prirodnih resursa, rada i socijalne politike, energetike, unutarnjih poslova i sigurnosti, zaštite okoliša i prirode i prostornog planiranja, graditeljstva i ljudskih prava. Rezultati autoričina istraživanja pokazuju da je u posljednja dva desetljeća u Hrvatskoj na djelu intenzivan proces agencifikacije posebno naglašen u okviru procesa pridruživanja i pristupanja Europskoj uniji.

Značajan je i autoričin prinos promišljanju tematike transparentnosti i otvorenosti vlasti. Kada se govori o dostupnosti informacija javnosti, često se koriste pojmovi transparentnosti, otvorenosti, slobode informiranja, prava na informiranost te načela javnosti i odazivnosti. Transparentnost nije isto što i otvorenost, s obzirom na to da je ona uokvirena propisima i predstavlja nužno sredstvo za realizaciju individualnih prava i nadzor vlasti. Otvorenost je pak utemeljena na političkoj odluci otvaranja prema javnosti kroz komuniciranje policy-opcija i raspravlja o njima. Po mišljenju autorice, transparentnost danas stoji uz bok načela vladavine prava, odgovornosti javne vlasti, efikasnosti, učinkovitosti dobrog upravljanja, koherentnosti javnih politika, participacije i inkluzivnosti.

Anamarija Musa u svom se radu posvetila i problematici lokalne samouprave. Pritom navlastito naglašava važnost višerazinskog upravljanja. Kao osnovne prioritete za bolje lokalno upravljanje koji jačaju kapacitet lokalnih vlasti za rješavanje problema navodi: 1) strateško upravljanje; 2) inovaciju i kvalitetu lokalnog upravljanja; 3) e-upravu za transparentnost i učinkovitost; te 4) pripremu lokalnih jedinica za članstvo u EU. Značajne su i autoričine opservacije o uporabi novih tehnologija u radu uprave pri čemu posebice naglašava primjenu e-uprave u digitalno doba. Niz je preuvjeta za novi način i filozofiju rada i funkcioniranja uprave, od strateškog pristupa, novih organizacijskih procesa, do jačanja upravnog kapaciteta, partnerstva s privatnim sektorom itd. U Europskoj uniji e-uprava smatra se ključnim pokretačem razvoja gospodarstva i društva. Hrvatska u tom smislu napreduje, ali još uvijek zaostaje, zbog sistemskih problema u svom javnom sektoru.

Važan je doprinos razvoju upravne znanosti u Hrvatskoj i autoričin rad u području razumijevanja tematike komora. Zajedno s kolegicom doc. dr. sc. Jasminom 
Džinić napisala je knjigu "Europska regulacija profesija i komora u Hrvatskoj". Profesije imaju značajnu ulogu u pružanju javnih usluga i u oblikovanju javnih politika. Profesija u osnovi uključuje visok stupanj znanja i vještina utemeljenih na obrazovanju ili usavršavanju, članstvu u profesionalnoj organizaciji s visokim skupom standarda za ulazak, posvećenost javnoj službi iznad osobnih interesa, te etički kodeks. Tradicija komorskog organiziranja na prostorima današnje Hrvatske seže još u 19. stoljeće kada su osnovane prve komore kao strukovne organizacije sa svrhom promicanja struke i zaštite svojih članova, ali i zaštite javnog interesa.

Najstarije komore osnovane su u području gospodarstva i obrta, arhitektonskih i inženjerskih djelatnosti, javnog bilježništva, liječništva, ljekarništva i odvjetništva. Donošenjem Ustava RH 1990. godine, građanima je zajamčeno pravo na slobodno udruživanje čime su stvoreni preduvjeti za ponovno osivanje komora. Karakteristika je takvih strukovnih organizacija u Hrvatskoj da pripadaju tzv. kontinentalnom tipu, odnosno jednopravnom modelu komora, kojemu je suprotan tzv. anglosaksonski tip odnosno privatnopravni model komora utemeljen na slobodnom, dobrovoljnom udruživanju.

Zajedno s kolegicom prof. dr. sc. Marčetić, doc. dr. sc. Anamarija Musa promišlja i problem europskih standarda službeničkog prava, zalažući se za to da europske norme iz tog područja budu primijenjene i u području lokalne i državne uprave $u$ Hrvatskoj, s posebnim naglaskom na djelovanje u javnom interesu, depolitizaciju i profesionalizaciju, odgovornost državnih službenika i zalaganje za uvođenje meritnačela. Anamarija Musa se, kao i dobar broj predstavnika(ca) zagrebačke škole upravne znanosti, bavi i problemom koordinacije u javnoj upravi, pokazujući širok interes za brojne aktualne teme, bilo da ih elaborira samostalno, bilo da prakticira kolaborativan rad sa svojim najbližim kolegicama.

Koordinacija per se ili kao proces podrazumijeva razvoj ideja o udruženom i holističkom djelovanju, dijalog između organizacija te procese planiranja i donošenja odluka. Koordinacija unutar političko-upravnog aparata može se realizirati trima različitim mehanizmima: hijerarhijskim, tržišnim i mrežnim. Pritom značajka je autoričina uvida komparativni pristup sa značajnim osvrtom na suvremene hrvatske prilike. I ovom prigodom moramo istaknuti da ovim sažetim pristupom nismo dotaknuli sve aspekte autoričina djelovanja i njezina doprinosa razvoju discipline.

Sljedeća autorica koja zaslužuje pozornost jest doc. dr. sc. Romea Manojlović. I ona se bavi velikim brojem tematskih područja upravne znanosti, reflektirajući o njima s interdisciplinarnog stajališta. Posebno nam se čine značajni autoričini pristupi razumijevanju i produbljivanju spoznaja o tematici lokalne samouprave u nizu europskih zemalja, a napose ustrojem lokalne samouprave u Danskoj, Grčkoj, Italiji i Saveznoj Republici Njemačkoj. Riječ je o značajnom prinosu organizacije i strukture lokalne samouprave u tim državama.

Kao zasebno područje zanimanja kolegice Manojlović valja naglasiti problem uređenja mjerenja učinka rada u hrvatskoj državnoj upravi i lokalnoj i područnoj samoupravi. Mjerenje učinka definira se kao niz aktivnosti kojima se prikupljaju informacije o različitim dimenzijama učinka pojedine upravne organizacije. Baveći 
se ovom kvantificirajućom metodom o radu uprave, autorica daje originalan doprinos hrvatskoj upravnoj znanosti. Smatra kako bi bilo poželjno da i hrvatski Državni ured za reviziju zauzme proaktivan stav te, osim na inpute, pozornost posveti i efikasnosti i troškovnoj efektivnosti, postizanju unaprijed zadanih rezultata i ishoda. Yakon je o proračunu propisao obvezu donošenja strateških planova za sva ministarstva i druga državna tijela. Ukupna doktrina upravljanja učinkom temelji se na stavu da se menadžerima mora dopustiti upravljanje jer su oni ti koji najbolje poznaju stanje pa će osigurati najveću kakvoću usluga za građane.

Doc. dr. sc. Goranka Lalić-Novak koautorica je sveučilišnog udžbenika „Upravna znanost“, ali i nekoliko knjiga i priručnika u kojima se bavi tematikom azila i migranata. U svom razmatranju o tim temama, autorica polazi od teze da je praktični problem način kako uskladiti hrvatske javne politike azila s međunarodnim standardima, standardima Vijeća Europe i pravne stečevine Europske unije o azilu s vrijednostima hrvatskog ustavnog poretka. Sam izraz azil potječe od grčke riječi asylos i označuje utočište, odnosno mjesto koje daje sigurnost i zaštitu od progona i opasnosti općenito. U starom i srednjem vijeku ta institucija, koja je religijskog podrijetla, vezana je za Crkvu. Povijesno promatrano, termin izbjeglica prvi se put primjenjuje na hugenote, francuske protestante koji su izbjegli iz Francuske 1685. godine.

Kao najvažniji mehanizam zaštite tražitelja azila i izbjeglica na području Europe jest Konvencija za zaštitu ljudskih prava i temeljnih sloboda. Na hrvatskom teritoriju, razvoj instituta pružanja utočišta moguće je pratiti od srednjeg vijeka. Srednjovjekovno razdoblje odlikuje se činjenicom da je azil postojao kao crkveni azil reguliran propisima kanonskog prava, dok je svjetovna vlast, donoseći pravila o azilu objašnjavala i detaljnije obrađivala važeće crkvene propise. Tek odlukom Marije Terezije o azilu iz 1796. godine, azil postaje institucija svjetovnog prava i ovisi jedino o slobodnoj kraljevskoj odluci. Pojam azila, navodi autorica, postoji u Statutu grada Splita iz 1312. godine, u Lastovskom statutu iz 1310. godine, te Šibenskom statutu iz 1383. godine u kojima se jamčilo utočište osobama u vrijeme blagdana svetaca, zaštitnika tih gradova.

Doc. dr. sc. Goranka Lalić-Novak donosila je i redovita izvješća SIGMA-e o napretku hrvatske države i provođenju reformi u području javne uprave, koji su za Hrvatsku bili rigorozniji nego za dobar broj zemalja kandidatkinja za prijam u EU. Autorica donosi i vrlo minuciozan problem migracija koji je $u$ današnjem trenutku posebno vezan za Europu, napose za Njemačku, a makar ovlaš i za Hrvatsku. Naravno da ne treba zanemariti činjenicu koliko je ova tema danas u fokusu interesa Katoličke crkve u Europi.

Doc. dr. sc. Jasmina Džinić koautorica je zapažene knjige o profesijama i komorama zajedno s kolegicom Anamarijom Musa. Ona se u svom radu, između ostalog, bavi i tematikom organizacijskog učenja u javnoj upravi. U kontekstu te teme daje vrlo opsežan prikaz glavnih pravaca organizacijskog učenja. U povijesnoj retrospektivi najprije predstavlja mehanicistički pristup, referirajući se na klasične autore poput Cyerta i Marcha te nobelovca Simona. Kod organizacijskog učenja, 
individualni koncept pamćenja zamijenjen je standardnim operativnim procedurama kao oblikom organizacijskog pamćenja koje se tijekom vremena mijenja. Drugi u nizu pristupa jest kibernetički pristup organizacijskom učenju, koji stavlja naglasak na razmjenu informacija dobivenih iz okoline. Kibernetika se definira kao teorija upravljanja i komunikacija kod strojeva i živih bića, te kao teorija ponašanja i strukture, usmjeravanja i reguliranja kompleksnih sustava. Jedan od najreprezentativnijih predstavnika kibernetičkog pristupa svakako je Buckley koji razlikuje dva temeljna procesa u sustavu, morfostazu i morfogenezu. Morfostaza se odnosi na one procese u složenim odnosima sustava i okoline koji tendiraju održavanju postojeće forme organizacije ili stanja sustava. Morfogeneza, u koju spada i učenje, obuhvaća procese koji tendiraju razradi ili promjeni postojećeg oblika organizacije i stanja sustava.

Pristup teorije stvaranja znanja težište stavlja na promatranje organizacije kao autopoetičnog sustava, kao onog koji je sposoban sam stvarati informacije koje mu omogućuju reprodukciju.

Sljedeći je pristup kulturološki. U kontekstu organizacijskog učenja ono se doživljava kao skladište događaja i lekcija iz prošlosti, koji se dalje prenose socijalizacijom. Smatra se da određena obilježja, odnosno komponente organizacijske kulture, kao što su primjerice proaktivan stav zaposlenika prema radu, suradnja među članovima organizacije i kontinuirana posvećenost unapređenju, mogu potaknuti razvoj organizacijskog učenja. Nakon toga prevladavaju menadžerske reforme javne uprave i organizacijsko učenje. Kao glavne uzroke novog javnog menadžmenta autorica navodi globalizaciju, rastuća očekivanja javnosti i razvoj informacijsko-komunikacijske tehnologije.

Javnu upravu smatralo se glavnim uzrokom makroekonomskih problema, pa se pretpostavljalo da će smanjenje javne uprave i prepuštanje djelatnosti organizacijama privatnog sektora obnoviti i povećati učinkovitost. U takvim okolnostima stvaraju se pretpostavke za učeću organizaciju.

Od mlađih predstavnica koje su već dostigle znanstvenu reputaciju valja navlastito spomenuti Petru Đurman koja se zajedno s Anamarijom Musa ogledala u pisanju tekstova o koordinaciji, zaključujući da je nedostatak policy-stručnjaka i tijela koja bi obavljala policy-analizu tradicionalno jedna od glavnih boljki procesa stvaranja javnih politika u Hrvatskoj. Također, ona je autorica i zapažene analize političko-upravnog sustava i organizacije lokalne samouprave u Velikoj Britaniji. Naposlijetku, Daria Dubajić dala je vrijedan obol tumačenju lokalne samouprave u susjednoj Sloveniji i procesu regionalizacije na njezinu teritoriju.

Iva Lopižić piše o procesu decentralizacije u lokalnoj samoupravi Francuske i o značajkama tog procesa.

Zaključno, mogli bismo ustvrditi da je ovaj prikaz nepotpun opis svih onih tema koje su apostrofirane nastavnice s Katedre upravne znanosti Pravnog fakulteta Sveučilišta u Zagrebu obradile. Ovaj prikaz imao je temeljnu nakanu pokazati kako se stvorila snažna grupacija nastavnica koje autoritativno pišu o temama koje dominiraju disciplinom upravne znanosti u europskim prilikama. Ne treba posebno 
naglašavati da svrha ovoga rada nije plod spolnih predrasuda, već je potaknut dobrohotnom spoznajom o snažnom intelektualnom imageu kolegica koje pokazuju široko znanje o ključnim problemima upravne znanosti, rabeći pritom komparativnu analizu i interdisciplinarnu metodu čime obogaćuju i druge discipline kao što su sociologija, politologija, ekonomija, psihologija, filozofija itd.

\section{LITERATURA:}

1. Đurman, Petra: Javna uprava i politički sustav Ujedinjenog Kraljevstva: Između tradicije i reformi, HKJU - CCPA Pravni fakultet Zagreb, Institut za javnu upravu, 15/1, str. 69-102, 2015., Zagreb.

2. Đurman, Petra - Musa, Anamarija: „Problem koordinacije u javnoj upravi. Natrag prema hijerarhiji?", Anali politološkog društva, god. X., Hrvatsko politološko društvo, Fakultet političkih znanosti, str. 111-138, 2014., Zagreb.

3. Koprić, Ivan et al.: Upravna znanost. Javna uprava u suvremenom europskom kontekstu, Pravni fakultet Sveučilišta u Zagrebu, Studijski centar za javnu upravu i javne financije, Suvremena javna uprava, str. 408., 2014., Zagreb.

4. Kregar, J. - Marčetić, G. - Grubišić, K.: Etika u politici i javnoj upravi, Novi informator, 2016., Zagreb.

5. Kregar, J. et al.: Decentralizacija, Centar za demokraciju Miko Tripalo, 2011., Zagreb.

6. Lalić-Novak, Goranka: Azil: Pravni i institucionalni aspekti, Pravni fakultet Zagreb, Studijski centar za javnu upravu i javne financije, 2016., Zagreb.

7. Lalić-Novak, Goranka: „Integracija stranaca i manjina u lokalnu zajednicu kao zadatak lokalne samouprave“, u: Građani, javna uprava, lokalna samouprava: jesu li mogući povjerenje, suradnja i potpora (Koprić, Ivan - Musa, Anamarija - Giljević, Teo (ur)., Institut za javnu upravu) str. 273-299, 2017., Zagreb.

8. Lalić-Novak, Goranka: „Stanje javne uprave prema izvještaju Europske komisije o napretku Hrvatske iz 2009.“, HJU, Institut za javnu upravu, god. 9., br. 4/2009., str. 941948, Zagreb.

9. Manojlović, Romea: „Javna uprava i politički sustav Savezne Republike Njemačke: Modernizacija kroz očuvanje tradicije“, Hrvatska komparativna i javna uprava, Institut za javnu upravu - Pravni fakultet Zagreb, No. 4., vol. 15., str. 141-173, 2015., Zagreb.

10. Manojlović, Romea: „Lokalna samouprava u Grčkoj“, Hrvatska javna uprava, Institut za javnu upravu, god. 9., br. 4/2009., str. 977-988, Zagreb.

11. Manojlović, Romea: „Lokalna samouprava u Republici Italiji“, Hrvatska javna uprava, Institut za javnu upravu, god. 8/2008., br. 4., str. 1087-1103, Zagreb. 
12. Manojlović, Romea: „Pravno uređenje mjerenja učinka u hrvatskoj državnoj upravi i lokalnoj i područnoj (regionalnoj) samoupravi“, Pravni vjesnik, PFO, Sveučilište Josipa Jurja Strossmayera, vol. 32., No. 1/2016., str. 7 -28, Osijek.

13. Marčetić, Gordana - Musa, Anamarija: „Europeizacija službeničkog prava: usklađivanje hrvatskog zakonodavstva s europskim standardima“, Zbornik radova Pravnog fakulteta u Splitu, god. 50., br. 3/2013., str. 725-756, Split.

14. Marčetić, Gordana: Javni službenici i tranzicija, Društveno veleučilište u Zagrebu, Konrad Adenauer Stiftung, 2005., Zagreb.

15. Marčetić, Gordana - Giljević, Teo: „Lokalna samouprava u Njemačkoj i Francuskoj“, $H J U$, Institut za javnu upravu , br. 1/2010., god. 10., str. 67-79, Zagreb.

16. Marčetić, Gordana: Upravljanje ljudskim potencijalima u javnoj upravi, Društveno veleučilište u Zagrebu, 2007., Zagreb.

17. Musa, Anamarija: Agencijski model javne uprave, Fakultet političkih znanosti, Studijski centar za javnu upravu i javne financije, 2014., Zagreb.

18. Musa, Anamarija - Džinić, Jasmina: Europska regulacija profesija i komore u Hrvatskoj, Institut za javnu upravu, 2012., Zagreb.

19. Musa, Anamarija, et al.: „Obrazovanje za javnu upravu: Pregled diplomskih programa javne uprave u zapadnoeuropskim zemljama“, I dio., Hrvatska javna uprava, Institut za javnu upravu, god. 7., br. 2/2007., str. 289-317, Zagreb.

20. Musa, Anamarija: Transparentnost - zašto i kako, Forum za javnu upravu, Friedrich Ebert Stiftung - Institut za javnu upravu, 2013., Zagreb.

21. Šeparović-Perko, Inge: Izazovi javnog menadžmenta. Dileme javne uprave, Golden marketing - Tehnička knjiga, 2006., Zagreb.

22. Šeparović-Perko, Inge: „Novi javni menadžment - britanski model“, Politička misao, FPZ, vol. XXXIX, br. 4/2002., str. 31 -43, Zagreb.

P.S. Riječ je o selektivnoj literaturi, dok je broj radova na hrvatskom i engleskom jeziku gotovo nepregledan i za ovu prigodu nužno ograničen. 


\section{NEW TRENDS IN DEVELOPMENT OF CROATIAN ADMINISTRATIVE SCIENCE}

This brief and unpretentiously written text has as it s main propose to warn on occurrence of new trends within recent croatian administrative science. $\mathrm{It}^{\prime} \mathrm{s}$ a fact that ever more female colleuge on Cathedra of administrative sciences of Faculty of Law University of Zagreb emerged as employees in scientific-educational vocation, which was once predominantly „male“ discipline.

Therefore, their autoritative and professional engagement in each aspect oft he discipline should be welcomed, from substantially traditional aspects to efforts on opening new thematic areas.

Especially great credit of female teachers of administrative science lies in process of europeization of croatian public administration and their endeavour to point out deficiencies in actual state and recomendations for their avoidance. In this way croatian administrative science catches connection on contemporary processes, within discipline in european context.

With it' $s$ width and coverage of themes, both ancient and new ones Croatian administrative science testifies it' $\mathrm{s}$ vitality and displays it can handle with corpus of positive law discipline et least on equall level

Keywords: public administration, transparency, regulation, agency, new public menagement, meritocracy, institutions, europeization 